\title{
Le Sueur v Faulks
}

Disciplinary Tribunal, Diocese of Peterborough, December 2007 Clergy discipline - financial records - conditional discharge

The complainant, an individual nominated by the PCC of Haselbech in the Diocese of Peterborough, brought forward a number of complaints against the respondent, the incumbent of the united benefice of which Haselbech is a part, under the Clergy Discipline Measure 2003, alleging neglect and inefficiency in the conduct of the duties of his office (section 8(1)(c) of the Measure) and conduct unbecoming or inappropriate to the office and work of a clerk in holy orders (section 8(1)(d)). The President of Tribunals found that there was a case to answer in five of the complaints: two concerning alleged irregularities in the levying of and accounting for fees for a particular wedding and three concerning alleged financial irregularity in the running of a parish magazine. The tribunal dismissed one complaint of inefficiency and neglect regarding the overcharging and subsequent repayment of fees for the wedding in question but found that the respondent was guilty of culpable inefficiency in failing properly to account to the PCC for the fees received. The further three complaints concerned the financial arrangements for the production and distribution of the magazine entitled Contact. The respondent claimed that this publication was a private community venture, produced and distributed by him and his wife, and financed by subscription and advertising income. However, the tribunal noted significant transfers of funds linked to income and expenditure relating to the magazine between the respondent and the various PCCs of the benefice. The tribunal considered that questions of financial accounting such as presented in this case fell within the arena of clergy discipline and that the PCCs had a legitimate interest in the publication of the magazine (although the PCCs were criticised for having for many years colluded with the unsatisfactory financial arrangements). The tribunal found that the respondent's failure to keep accurate financial records and failure to present accounts to the PCC amounted to neglect and inefficiency in the performance of his duties. The final allegation, of conduct unbecoming, related to a failure by the respondent and his wife to account for any of the profits from the magazine. The exact sum, of perhaps a few hundred pounds over a three-year period, was impossible to quantify, owing to inadequate record-keeping. The tribunal found that the respondent did not intend to deal dishonestly or to gain financially from the magazine but found that his failure properly to account for surpluses accrued amounted to financial conduct unbecoming a clerk in holy orders. Taking into account mitigating factors including the respondent's ill health, the lengthy period during which he was suspended from one of the four parishes in the united benefice and the finding that he was not dishonest or deliberately deceptive, no penalty was imposed and the respondent was conditionally discharged 
for two years. The tribunal considered it a matter of some regret that the PCC had declined to go down the route of conciliation initially advocated by the bishop. [WA]

\section{Eweida v British Airways plc \\ Reading Employment Tribunal, January 2008 \\ Religious discrimination - cross - uniform}

The claimant, a committed Christian, was employed by the respondent from 1999 as a member of the uniformed airport check-in staff. Between 1999 and 2004 she had habitually (though not always) worn a silver cross on a chain round her neck. This cross was concealed beneath the high-necked uniform blouse. In 2004 the uniform changed, whereby items of jewellery or other adornment which would formerly have been concealed became visible. The respondent's uniform policy forbade the wearing of any jewellery. The claimant reported for work on a number of occasions with her silver cross visible. When she refused to conceal the cross she was sent home and remained at home and unpaid between September 2006 and February 2007, when the uniform policy was changed to allow the visible wearing of a faith or charitable symbol and she returned to work. The claimant complained of discrimination, indirect discrimination and discrimination by harassment under the Employment Equality (Religion or Belief) Regulations 2003, SI 2003/1660. During the course of the case, the tribunal also invited and heard a complaint that the respondent had unlawfully stopped the claimant's pay during the time she remained at home.

The claimant's allegation of discrimination centred on the uniform policy but also included complaint against the respondent's rostering system, its management of break times for employees, a perceived anti-Christian bias in company policy and training materials and its former provision of a Qur'anic entertainment channel on certain flights for part of her period of employment. The tribunal found no evidence of religious discrimination in any of these secondary matters and, on the contrary, found that the rostering system was flexible enough to allow the claimant to attend worship on a Sunday, albeit with a certain amount of effort on her part, and that the system for rostering Christmas Day was fair and not discriminatory.

The claim that the uniform policy and its management were discriminatory was backed by evidence that employees of other faiths were permitted to wear visible garments and symbols of that faith, whereas the claimant, 